\title{
Fitorremediazioa lurzoru kutsatuen kudeaketa iraunkorrerako estrategia gisa
}

\author{
Phytoremediation as an strategy for sustainable management \\ of contaminated soils
}

\author{
María Teresa Gómez-Sagasti*1, Lur Epelde ${ }^{2}$, Oihana Barrutia ${ }^{3}$ \\ ${ }^{1}$ Zientzia eta Teknologia Fakultatea, UPV/EHU \\ ${ }^{2}$ NEIKER-Tecnalia \\ ${ }^{3}$ Hezkuntza, Filosofia eta Antropologia Fakultatea (Irakasleen Eskola), UPV/EHU
}

LABURPENA: Iraunkorrak eta (eko)toxikoak izan ohi diren konposatu ez-organiko eta organikoen isurketa masiboek potentzialki kutsatuta egon daitezkeen lurzoruen kopurua izugarri handitu dute. Lurzoruen osasuna (funtzionalitatea) eta kalitatea (emankortasuna) arrisku larrian egoteak eta, ondorioz, giza biziraupena estutasunean jartzeak lurzoru kutsatuen kudeaketa eraginkorra mundu mailako ingurumen-politiken premiazko jomugan paratu du. Gaian sartuta, lan honen helburu nagusiak hauek dira: (i) lurzoru kutsatuen kudeaketaren lege eta jarduera markoa aurkeztea; (ii) lurzoru kutsatuen kudeaketa eta arriskuen ebaluazioa aztertzea, eta, azkenik, (iii) ohiko erremediazio-teknika suntsitzaileen aitzinean, fitorremediazioaren arloan egiten ari diren esfortzu zientifiko-teknikoak argitara ekartzea. Lurzoru kutsatuen kudeaketan aurrerapenak egiteko landu beharreko hariak ere laburki iruzkintzen dira.

HITZ GAKOAK: lurzorua, kutsadura, fitorremediazioa, osasuna, bioindikatzaileak, gizarte-inpaktua.

ABSTRACT: The massive emissions of persistent and (eco)toxic inorganic and organic compounds have drastically increased the number of potentially contaminated soils. As soils' health (functionality) and quality (yield), which in turn compromise human survival, have been seriously endangered, the effective management of contaminated soils has become a priority objective for global environmental policies. Thus, the main objectives of the present work are: (i) introduce the legal framework for the management of contaminated soils; (ii) analyse the management and risk assessment of contaminated soils and; finally, (iii) in front of conventional destructive techniques, clarify the scientific and technical advances that are being carried out in the field of phytoremediation. The topics to be developed in order to progress in the management of contaminated soils are also briefly exposed.

KEYWORDS: soil, contamination, phytoremediation, health, bioindicators, social impact.

\footnotetext{
* Harremanetan jartzeko / Corresponding author: María Teresa Gómez-Sagasti. Landare Biologia eta Ekologia Saila, Zientzia eta Teknologia Fakultatea, UPV/EHU, Sarriena Auzoa, zg, 48940, Leioa, Bizkaia, Euskal Herria. - mariateresa.gomez@ehu. eus - https://orcid.org/0000-0003-4412-151X.

Nola aipatu / How to cite: Gómez-Sagasti, María Teresa; Epelde, Lur; Barrutia, Oihana (2019). «Fitorremediazioa lurzoru kutsatuen kudeaketa iraunkorrerako estrategia gisa»; Ekaia, 35, 2019, 197-212. (https://doi.org/10.1387/ekaia.19633).

Jasoa: 8 maiatza, 2018; Onartua: 20 iraila, 2018.

ISSN 0214-9001 - eISSN 2444-3255 / (c) 2019 UPV/EHU
}

(c) (i) (9) Obra hau Creative Commons Atribución 4.0 Internacional-en lizentziapean dago 


\section{SARRERA: LURZORUEN FUNTZIOAK ETA JASATEN DITUZTEN MEHATXUAK}

Azken mendean, munduko biztanleria ia laukoiztu egin da. Eztanda demografiko horren giltzarriak nekazaritzan eta industrian gertatu diren aurrerakuntza zientifiko-teknologikoak dira. Giza ongizatearen hobekuntzak egungo hiperkontsumoa areagotu du (elikagaiena, energiarena zein teknologiarena), eta, aldi berean, industrializazioan eta elikagaien ekoizpenean etengabeko presioa ezarri du. Are gehiago, garapen iraunkorrari buruz argitaratu diren azken txostenek gizadiak planetaren jasate-ahalmena dagoeneko gainditua duela azpimarratzen dute [1]. Hortaz, adituen aburuz, planeta mailako benetako larrialdi batean gaude murgilduta. Lur emankorren kudeaketa intentsiboak, industrien garapenak eta (mega)hirien hedapenak, tamalez, lurzoruen «osasuna» hondatu dute, eta baita haien «kalitatea» ere. Nahiz eta lurzoru-zientzietan oso eztabaidatuta dauden kontzeptuak izan, oro har, lurzoruaren osasuna «sistema bizidun moduan funtzionatzeko lurzoruak daukan gaitasuna» dela esaten da (ikuspuntu biologikoa). Lurzorua biozenosi ugari baten euskarria da; hain zuzen ere, ezagutzen diren espezie guztien laurdenak lurzoruan bizi dira. Lurzorua euskarri duten sare trofikoko parte-hartzaileak lurzoruaren funtzio naturalak modu egokian aurrera eramateko ezinbestekoak dira, zeren, besteak beste, energia eta mantenugaiak birziklatzen (ziklo biogeokimikoetan), ura iragazten eta kutsatzaileak indargetzen laguntzen baitute. Hala, lurrazalaren biodibertsitatea funtsezkoa da etorkizuneko janari-ekoizpena eta elikadura-segurtasuna bermatzeko [2]. Lurzoruaren kalitatea, aldiz, «erabilera zehatz baterako duen egokitasunarekin edo emankortasunarekin» lotzen da (ikuspuntu antropozentrikoa). Osasuna ez bezala, kalitatea lurzoruaren funtzio materialekin erlazionatuta dago, hau da, eskaintzen dituen zerbitzu ekologikoekin - esaterako, lehengai berriztagarrien eta ez-berriztagarrien hobia, etxebizitzen eta azpiegituren kokalekua, eta oinordetza kulturalaren artxibategia izatearekin, besteak beste- .

Baliabide edafikoen erabilera desantolatuak lurzoruaren degradazioa areagotu du. Funtsean, giza jardueretan jatorria duten ekintza fisikoek (adib. higadura, zigilatzea eta trinkotzea) eta kimikoek (adib. azidotzea, gazitzea, materia organikoaren galera eta kutsatzaileen sarrera edafosferan) lurzoruen osasuna/kalitatea andeatu dute. Alde horretatik, ez dugu ahaztu behar lurzorua giza eskalan berrizta ezin daitekeen baliabide estrategiko bat dela [3]. Esku artean duzun lan honek lurzoruaren kutsadura du ardatz, mundu mailako mehatxu esanguratsuenetariko bat baita organismo bizidun guztien biziraupena (gizakiena barne) kolokan jartzen duena. Europar Batasunean (EB) lurzoruaren kutsadura hegoaldeko zein iparraldeko herrialdeetan errotzen den arazo/«gaixotasun» ekologiko handienetako bat da. 2014an EBk plazaratutako lurzoruen inbentarioak egoera atsekabegarri bat jarri zuen agerian: Europa mailan 2,5 milioi gune inguru 
daude potentzialki kutsatuta, eta horietatik ia \% 15ek ( 0,35 milioik) kutsadura-maila altua du, eta, ondorenez, errehabilitazio-behar larria [4]. Kontsultatutako txostenaren arabera, meatzaritzak, industria astunek zein nekazaritza-praktika erasotzaileek lurzoru kutsatuen arazoa areagotzen dute. Kutsatzaile ohikoenak hauek dira: metalak (adib. zinka $-\mathrm{Zn-;}$;obrea $-\mathrm{Cu}-$, beruna $-\mathrm{Pb}-$, merkurioa $-\mathrm{Hg}-$ eta kadmioa $-\mathrm{Cd}-$ ) eta metaloideak ( $a d i b$. artsenikoa $-A s-$ eta selenioa $-S e-$ ), pestizidak (bereziki konposatu organiko aromatikoak, DDT bezalakoak) eta olio mineralak (adib. hidrokarburo erregaiak). Bestalde, farmazian, biomedikuntzan, elektronikan eta materialen zientzietan egindako aurrerapenek kutsatzaile berriak (adib. antibiotikoak, plastifikatzaileak eta nanomaterialak) sorrarazi dituzte. Horretaz gain, aipatutako kutsatzaileak airean eta uretan erraz barreiatzen direnez, kutsadura iturritik urrun dauden lurzoruetara ere heda daiteke. Kutsadura difusoaren hedadura gutxiago ezagutzen den arren, ziurrenik milaka kilometro koadro lurzoru mehatxatuta leudeke [5]. Gainera, aipatutako kutsatzaileak maiz agertzen dira lurzoruan nahasita, eta horrek erronka berri bat gehitzen dio lurzoru kutsatuaren berreskurapenari.

«Desindustrializazio»aren eta meatzaritza- zein metalurgia-jardueren eraistearen ondorioz, abandonaturiko industria-lurzoruak (ingelesez, brownfield deiturikoak) ugarituz joan dira. Eremu horiek, ekonomiaren eta ingurumenaren arloan ez ezik, eskualdeko gizartearen ongizate eta bizi-kalitatean ere izan ohi dituzte ondorio kaltegarriak [6]. Euskal Autonomia Erkidegoa (EAE) lurzoru abandonatu eta kutsatuen kasuistika askotarikoa duen lurralde bat da, gutxi gorabehera $7.200 \mathrm{~km}^{2}$-ko azalera eta 2 milioi biztanle baino zertxobait gehiago izanik [7]. Agidanez, EAEko industrializazioaren hastapenetan izandako ingurumenarekiko kontzientzia-falta, urbanismo desantolatua, 1980tik aurrera izandako desindustrializazioa eta kontrolik gabeko hondakin-isurketak daude erkidegoak jarauntsi dituen lurzoru abandonatu, kutsatu eta degradatuen zergatien artean. IHOBEk (Eusko Jaurlaritzaren Ingurumen Jarduketarako Sozietate Publikoak) dauzkan datuen arabera, iraganeko eta egungo industria-jarduerek oinordetzan 12.331 lursail kutsatu utzi dituzte, zeinek 9.337 ha okupatzen dituzten, hau da, erkidegoaren azalera guztiaren \% 1,1 eta jarduera ekonomikoek okupatzen duten lurraldearen \% 67 [7].

\section{ERREFERENTZIAZKO LEGE-MARKOAREN BERRIKUSKETA}

EBn airearen eta uraren kalitatea babesteko indarrean dauden lege multzo espezifikoekin alderatuta, lurzoruen babeserako araudia atzerapen nabarmenarekin garatzen ari da. Izan ere, lurzoruaren $\mathrm{ku}$ - 
tsaduraren eboluzio motela, ondorioak epe ertain-luzera azaleratzea eta kutsadurari aurre egiteak eskatzen duen diziplinarteko lankidetza daude, hein batean, aipatutako araudiaren atzerapenaren oinarrian. Horiek horrela, Europako herrialde bakan batzuek lurzoruaren babeserako legedi espezifiko propioa daukate, hala nola Herbehereek, Alemaniak eta Danimarkak.

EBk dagoeneko lurzoruaren suntsipena «arazo larria» dela aitortu du. Hala eta guztiz ere, 2014an, Europako Parlamentuak lurzoruaren babeserako estrategia tematikoan (COM(2012)46) landutako behin-behineko zuzentarauaren zirriborroa atzera bota zuen, zenbait estatuk (besteak beste, Alemaniak eta Erresuma Batuak) proposamena zortzi urtez blokeatuta eduki ondoren. Aipatutako lurzoruen babeserako zuzentarauak EBn ikuspegi bateratua ezarriko luke, eta, horri esker, gobernuek mehatxupean dauden eremuak identifikatu, lurzoruen egoerari buruzko datuak bildu eta elkarren artean partekatuko lituzkete. Halaber, zuzentarau horrek lurzoruetako kalteak arintzeko programa nazionalak bultzatuko lituzke, nahiz eta herrialdeen eskuetan egon martxan jartzeko erabakia, eta baita diseinua ere. Gaur egun, beraz, lurzoruaren babes juridikoa lehendik garatutako politiketan integratzen da, eta, momentuz, ez da autonomoki lantzen (ikus 1. irudia). Horrela, lurzoruaren babesa bestelako zuzentarauetan urardotuta dago.

Nahiz eta gobernu askok lurzoruaren kutsadura nazio mailako arazoa dela azpimarratu, azken urteotan gutxi izan dira lurzoruak kutsaduratik babesteko xedearekin estatuko edo/eta eskualdeko lege berriak onartu dituztenak (1. irudia). Espainian, 1995. urtean Lurzoru Kutsatuak Berreskuratzeko Plan Nazionala onartu zen, eta geroztik autonomi erkidegoak (AE) beren ekintza-planak sustatuz joan dira. 10/1998 eta 3/1998 Legeek [8], Estatu eta EAE mailakoak hurrenez hurren, lurzoru kutsatuaren kontzeptua Espainiako eta Euskadiko sistema juridikoan txertatu zuten. Lurzoru kutsatua «ezaugarri fisiko, kimiko edo biologiko guztiak modu negatiboan eraldatuak dituen lurzorua da, oro har giza jatorriko osagai arriskutsuen presentzia dela medio, giza osasuna zein ingurumena arriskuan jartzen duten kontzentraziotan, Gobernuak finkaturiko irizpide eta estandarren arabera» (10/1998 Legea, 3.p art.). Horrekin batera, aipatutako 10/1998 Legeak autonomia-erkidegoei lurzoru kutsatuak deklaratzeko, mugatzeko eta inbentariatzeko beharra ezarri zien. Baina lurzorua baliabide bat da, eta, beraz, ezin da hondakin moduan tratatu. Lurzorua, «babes-objektu» den heinean, bere autonomia mantentzeko ezinbestekoa da hura baliabidetzat hartzea, airea eta ura bezala. Baliabide gisa, baliabide kutsatua izan daiteke, baina ez hondakina. 22/2011 Legeak, hondakin eta lurzoru kutsatuei buruzkoak eta lurzoru kutsatuen erregimen juridikoa arautzen duenak, aurreko legea indargabetu eta V. tituluan lurzoru kutsatuen erregulazioa jorratzen du. 


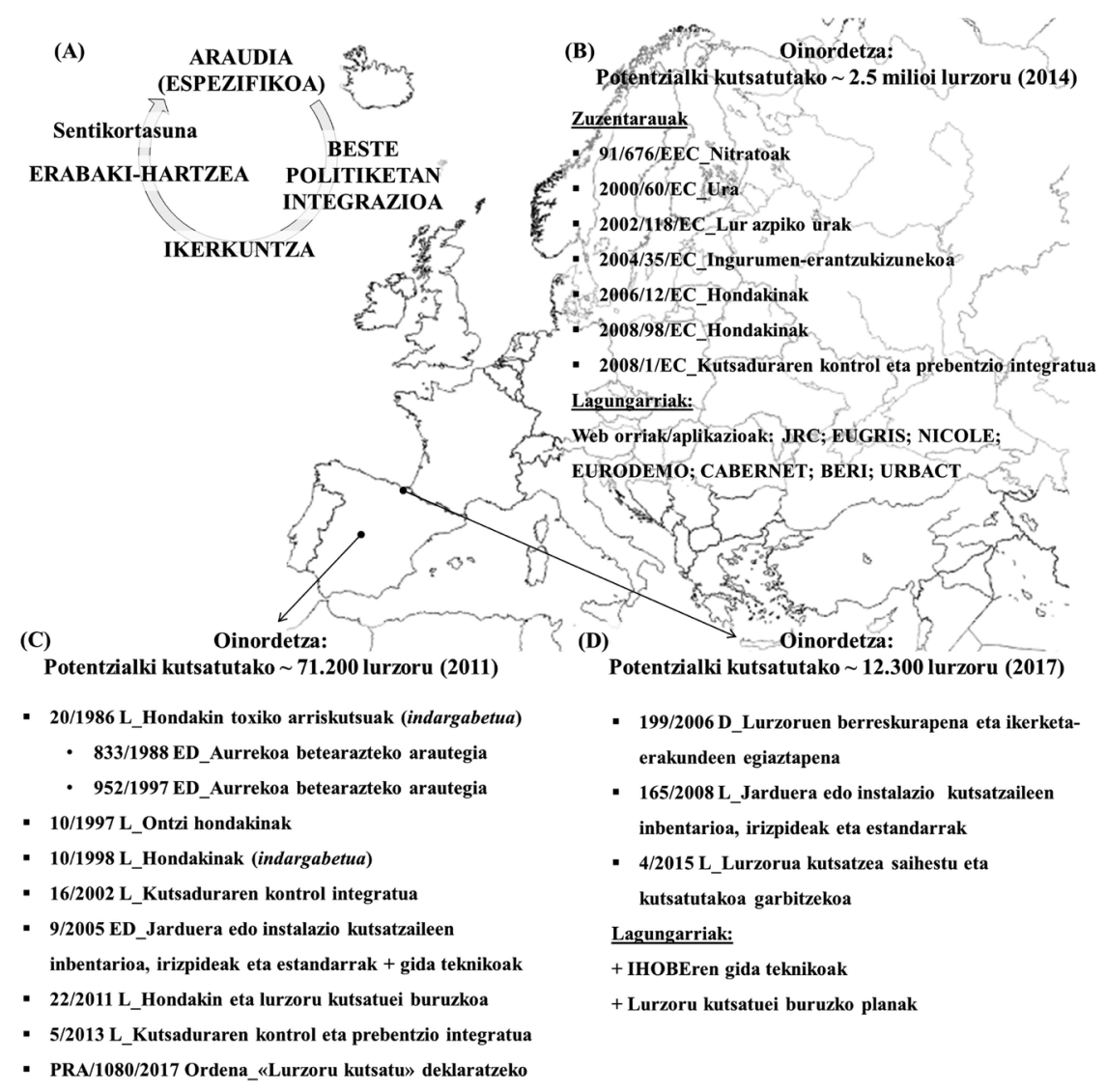

1. irudia. Lurzoru kutsatuei buruzko arautegia bultzatzen duen motorra (A), ingurumen planak eta lagungarriak izan daitezkeen dokumentu teknikoak Europar Batasunean (B), Espainian (C) eta Euskal Autonomia Erkidegoan (D). D: Dekretua; ED: Errege Dekretua; L: Legea.

Lurzoruaren kalitatearen arloan norbanakoek eta herri-administrazioek egin beharreko ekintzei legezko estaldura emateko asmoz onartu zen 9/2005 Errege Dekretua, urtarrilaren 14koa, lurzorua kutsa dezaketen jarduerak zerrendatu eta lurzoru kutsatuak izendatzeko irizpideak eta estandarrak ezartzen dituena. Jarraian, Eusko Legebiltzarrak Lurzorua Ez Kutsatzeko eta Kutsatutakoa Garbitzeko 2005eko otsailaren 4ko 1/2005 Legea onartu zuen. Biek lurzoruari ondasun juridikoaren entitatea eman zioten, eta prebentziorako eta kutsadura saihesteko zein arriskuak ebaluatzeko neurriak ezarri zituzten. EAEn hiru harroin ezarri ziren: aurrena, lurzoruetan eralda- 
keta berriak agertzea saihestea; bigarrena, kasurik premiazkoenak konpontzea; eta, azkenik, kutsatutako lurzoru gisa oinordetzan hartutako pasiboa epe ertain eta luzera konpontzeko plangintza bat egitea. Era berean, 1/2005 Legeak lurzoru kutsatuaren definizioa osatu zuen: «gizakiaren ekintzen eraginez ezaugarri kimikoetan eraldaketaren bat duen lurzoru oro da, baldin eta eraldaketa hori, ingurumenerako zein pertsonen osasunerako ezin onartuzko arriskua duelako, bere funtzioekin bateraezina bada, bai egungo erabilerarako bai erabilera aldatuz gero hurrengo baterako». Galdera zera da: zer ulertzen da «arrisku ezin onartuzko»tzat? Arriskuaren balioespen objektiboa bilatzeko eta administrazioen eskumena kontrolatzeko asmoz, ordenantza gehienek erreferentziazko balio edo irizpideak zehaztera jotzen dute; horiek gaindituta, lurzorua kutsatuta egoteko aukera egon ez ezik, giza osasunarentzat edo ingurumenarentzat arrisku onartezina egon daiteke [9]. Hala, bada, arriskuen ebaluazioa ezinbesteko tresna da, onartezintasuna baieztatzeko edo errefusatzeko. Geroago, 26/2007 Legeak, urriaren 23koak, ingurumen erantzukizunari buruzkoak, «kutsatzaile-motak», «kaltea», «arriskua» eta antzeko kontzeptuak zehaztu zituen. 2015ean, Eusko Legebiltzarrak lurzoruaren kutsadura saihesteko eta kutsatutakoa garbitzeko ekainaren 25eko 4/2015 Legea onartu zuen, zeinak berreskurapenerako alternatibaak aztertzeko betebeharra adierazi eta lurzoru kutsatuen berrerabilerarako interesgarriak izan daitezkeen alderdi tekniko, ekonomiko zein ingurumenekoak ere integratzen dituen. Berritasun gisa, eta Garapen iraunkorrerako 2002-2020 tarterako EAEko ingurumen-estrategiaren barruan, «Lurzorua Babesteko 2020rako Estrategia»ren lehenengo idazkiak mahai gainean omen daude. EAEko Lurzoru Kutsatuei buruzko 2007-2012 tarterako Planaren printzipioak abiapuntu moduan edukita, estrategia berri honek, antza denez, lurzoruaren erabilera eraginkorraren inguruko kontzeptuak bereganatuko ditu (Europako bide-orria COM(2011)571). Itxuraz ere, eraikitzen ari den estrategia horretan enfasi berezia jarriko omen zaio lurzoruaren «degradazio garbia zero» izateari, zeina Garapen Iraunkorrari buruzko Nazio Batuen Batzarrean (Rio+20) mahaigaineratutako helburu-sorten artean dagoen.

Lurzoruaren babeserako garapen bidean dauden arauzko eskakizunek berreskurapen/erremediazio-proiektuei lurzoruaren osasunaren/kalitatearen inguruko ikuspegi holistikoa eskatzen diete. Ikuspegi horren arabera, ez da soilik kutsatzaileen kontzentrazioa kontuan hartzen, baizik eta baita lurzoruaren bestelako ezaugarri kimiko, fisiko eta biologiko batzuk ere, horien arteko elkarreragina funtsezkoa baita lurzoruaren funtzionamendu egokirako [10].

\section{LURZORU KUTSATUEN KUDEAKETA PROZESUA}

Lurzoruen kutsadurak duen garrantzia ikusarazteko, arazoaren inpaktu ekonomikoari erreparatu behar diogu. Europako Ingurumen Agentziaren 
(EIA) arabera, batez beste lurzoru kutsatuen kudeaketaren gastu osoaren $(\sim 6,5$ biloi euro urtero) $\% 42$ aurrekontu publikoetatik etorria da. Urtero kutsatutako lurzoruak kudeatzeko estatuko gastua, batez beste, $10,7 €$ per capita da, Barne Produktu Gordinaren \% 0,04. Nahiz eta Estatuko gastuen \% 81 erremediazio-neurrietara zuzenduta egon, ikerkuntzan bakarrik \% 15 inbertitzen da [4]. Honako hauek dira kontuan hartzeko moduko beste datu batzuk: lurzoru kutsatu potentzialen ikerketa-kostuak, oro har, 5.000-50.000 € dira, eta erremediazio-proiektuen kostuak 50.000$500.000 €[4 ; 11]$. Erremediazio-prozesuaren fase guztietan zehar interesatuen parte-hartzea aldez aurreko betekizun inportantea da erabakia hartzeko prozesua hobetzeko [6]. Interesatuak (stakeholderrak) lurzoruen jabeak, planifikatzaileak, aholkulariak, erregulatzaileak, tokiko komunitateak, inbertitzaileak eta aseguruak izan daitezke.

Lurzoruen kudeaketak ondoz ondoko bost eustazpi eduki beharko lituzke: (i) prebentzioa; (ii) lurzoruaren karakterizazioa; (iii) arriskuen karakterizazioa, ebaluazioa eta erabaki-hartzea; (iv) erremediaziorako estrategiaren hautespena, diseinua, inplementazioa eta jarraipena, eta, azkenik, (v) aurrera eramandako kudeaketaren emaitzen bilketa eta transferentzia. Hirugarren eustazpi horren muinean, Arriskuen Ingurumen Ebaluazioa (AIE) (ingelesez, Environmental Risk Assessment -ERA-) kokatzen da, ekosistemen kutsadurak ekartzen dituen arriskuak kalkulatzeko ingurumeneko datuak biltzen, antolatzen eta aztertzen dituen prozesua [12]. Hala ere, lurzoru kutsatuen ingurumen-arriskuak ebaluatzea zailtasunez josita dago. Lurzoruen izaera heterogeneoa dela eta, sarritan, lurzoruaren kutsadura ez da uniformea izaten, eta, ondorioz, zehazteko zailagoa izan ohi da. Edozein arriskuren ebaluazioan, baita AIEn ere, aztertu beharreko oinarrizko faktoreak ekuazio honetan laburbildu daitezke: «arriskua = esposizioa $x$ arriskubidea edo inpaktua (x kalteberatasuna)» (ikus 2. irudia). Sarritan, AIE segidako fase edo mailetan hierarkizatuta dago. Gehienetan, aurretiazko karakterizazio batekin hasi eta arriskuaren karakterizazio, komunikazio eta kudeaketarekin jarraitzen du. Azken maila horretan, eta lurzoruari eman nahi zaion erabileraren arabera, gara daitezkeen estrategien inguruko erabakiak hartzen dira, tartean bio/fitorremediazioa (2. irudia).

Zabalki onartuta dago ez dela posiblea lurzoruaren kutsatzaileen inpaktua ebaluatzea haien kontzentrazioa bakarrik neurtuz, horrek kutsadurari buruzko informazioa soilik ematen baitu, eta ez poluzioari buruzkorik [13]. Alde horretatik, kutsadura deritzo substantzia bat egon behar ez lukeen lekuan edo eremu horretarako jatorrizko maila naturala gainditzen duen kontzentrazio batean topatzeari. Poluzioa, berriz, organismo egoiliarrengan kontrako eragin biologikoak sortzen dituen kutsadura gisa defini daiteke. Horregatik ez da arraroa AIEn, nabaritasun lerro kimikoaz (kontzentrazio totalaz) gain, toxikologikoa eta ekologikoa ere jorratzea (TRIAD hurbilketa) (2. irudia) [13]. 


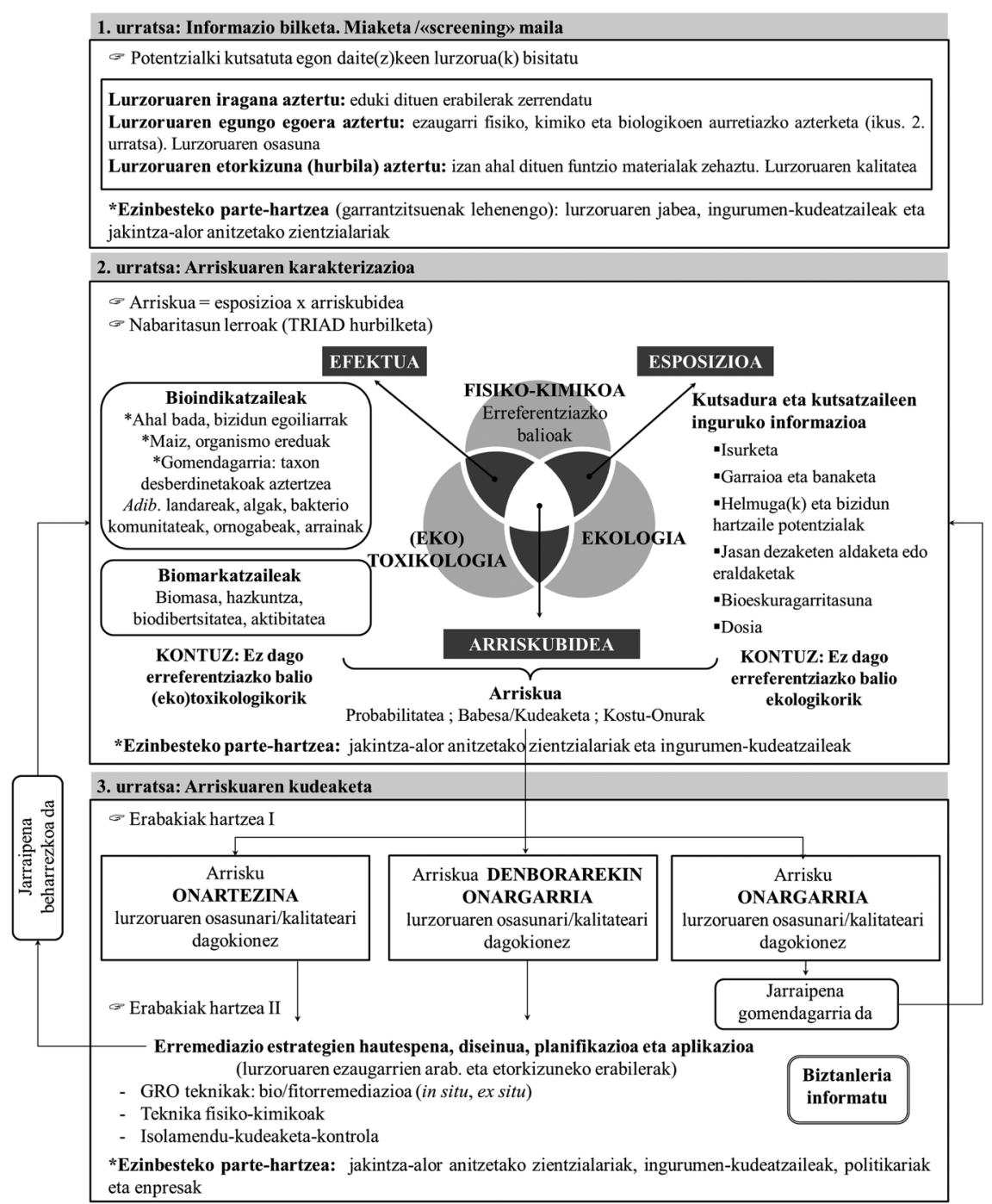

2. irudia. Lurzoru kutsatuen Arriskuen Ingurumen Ebaluazioaren (AIE) eskema orokorra.

Kutsatzaileek eragindako kontrako efektu biologikoak aztertzeko edo, beste era batera esanda, horiek lurzoruaren osasunean izan ditzaketen inpaktuak analizatzeko, erreminta biologikoak (bioindikatzaileak eta biomarkatzaileak) erabiltzen dira. Adierazle horiek indikatzaile kimikoekin alderatuta, azkarragoak, sentikorragoak, zehatzagoak, integratzaileagoak eta kostu-efektiboagoak direla frogatu da [14]. Bioindikatzaileek (or- 
ganismo edo komunitate bizidunek) eta/edo biomarkatzaileek (bizidunarengan gertatzen diren aldaketa molekular, biokimiko, fisiologiko edo morfologiko neurgarriek) emandako erantzunak tradizionalki kutsatzaileen kontzentrazio total eta bioeskuragarriekin konparatzen dira, kausaondorio harremanak ezartzeko asmoz (kausa: kutsatzaileen kontzentrazioa; ondorioa: erantzun biologikoa) [13]. Hala ere, erantzun biologikoak Kimikaren argitan baino Biologiaren argitan interpretatzearen premia ikusi da. Hari beretik, kutsatutako edo berreskuratutako lurzoruentzat, datu biologikoetatik abiatuz arauzko mugak ezartzearen aukera kontuan hartu beharko litzateke. Epelde et al.-en arabera [15], fitorremediazioestrategien eraginkortasuna kutsatzaileen alderditik zein ekosistemen zerbitzuen hornikuntzaren alorretik (hau da, karbono-bahiketa, lehengaien ekoizpena, higaduraren kontrola, balio estetikoa) ebaluatu beharko litzateke. Lurzoruaren ezaugarriak, hala nola lurzoruko ezaugarri mikrobiologikoak, ekosistemen zerbitzuei edo atributu ekologikoei (adib. indarra, antolaketa, egonkortasuna, gaitzen aurreko supresibitatea, erredundantzia) erreparaturik sailka daitezke. Ikuspegi hori lagungarria izan daiteke epe luzeko jarraipen-programetan, goi-mailako kategoria horiek, metodoen edo interesen aldaketen gainetik, denboran zehar egonkortasuna ematen dutelako.

\section{LURZORU KUTSATUEN BERRESKURAPEN BIOLOGIKOA HELBURU}

Inplikazio ekonomikoak eta teknikoak direla eta, lurzoruen berreskurapena zailtasunez beteta dago. Ingeniaritza zibilaren ohiko teknika fisikokimikoak bazter utzi beharko lirateke, zeren lurzoruaren egituran, konposizio kimikoan eta biozenosian atzeraezinak diren eraldaketak sorrarazten baitituzte (adib. garbiketa, indusketa eta errausketa), eta sargai baxuko erremediazio aukera bigunen erabilera lehenetsi beharko litzateke (adib. biorremediazioa eta fitorremediazioa) [5]. Erremediaziorako aukera bigunak (ingelesez, Gentle Remediation Options, GRO) lurzoru kutsatuen arriskuen kudeaketarako estrategiak edo teknikak dira, lurzoruen funtzionaltasun ekologikoan murrizketa gordinak eragiten ez dituztenak [16]. Hemendik aurrera GRO laburdura erabiliko dugu teknika horiei erreferentzia egiteko. Beraz, erremediazio-aukera horiek lurzoruak «osasuntsu» eta «biologikoki emankor» mantentzeko erabilgarritasun berezia daukate. Era egoki batean aplikatuta, GRO horiek abantaila hauek eskaintzen dituzte: (a) arriskuen kudeaketa azkarra puntu kritikoak (iturria[k]-bidea[k]-hartzailea[k]) kontrolatuz; eta (b) bestelako onura ekonomikoak (adib. biomasa sortzea), sozialak (adib. balio hezigarria eta aisialdirakoa), baita onura ekologikoak ere (adib. $\mathrm{CO}_{2}$-aren atxikipena) [ikusi 5 eta hango erreferentziak; 16]. Kapital-kostuak erlatiboki txikiak izatea eta landatutako guneei datxekien estetika bera ere GROen abantailen artean daude $[16,17]$. 
Erremediaziorako aukera bigunek biorremediazioa, fitorremediazioa eta antzeko bioteknologiak barne hartzen dituzte. Izatez, biorremediazioa mikroorganismoek bideratutako berreskuratze-prozesua da. Fitorremediazioan, ordea, landareak eta haiei loturiko mikroorganismoak dira teknologiaren ardatz nagusiak. Onura ekonomikoan oinarrituta, fitorremediazioan, teknika bat baino gehiago egon arren (3. irudia), funtsean hiru estrategia nagusi bereiz daitezke: (i) metalen erauzketan oinarritutako onura ekonomikoa (fitoerauzketa); (ii) arriskuaren minimizazioa (fitoegonkortzea), eta (iii) lurzoruaren kudeaketa iraunkorra (fitokudeaketa), zeinean fitorremediazioak etengabe areagotzen duen lurzoruaren emankortasuna, hurrengo hazkuntza-zikloetan balio ekonomiko erantsia duten laborantzetarako bidea emanez. Horietaz gain, biomasa handiko eta hazkunde azkarreko landareak, zuhaitzak kasu, energia-ekoizpena eta fitorremediazioa aldi berean lortzearen xede bikoitzarekin ere ustiatzen dira.

Hainbat ikerketak GROen potentziala nabarmendu dute, fitorremediazio-teknikena batez ere, kutsatzaileak lurzorutik erauzteko edo bertan egonkortzeko/ibilgetzeko [5]. Edozein fitorremediazio-teknologiaren arrakasta oinarrizko hiru faktore hauen elkarrekintzaren araberakoa da: (i) landare espeziearen izaera, (ii) lurzoruko mikroorganismoen komunitatea (iii) eta kutsatzaileen ezaugarri fisiko-kimikoak. Lan honen lehenengo atalean aipatu den bezala, gainera, lurzoru kutsatu gehienak kutsatzaile organiko eta ez-organikoekin aldi berean kutsatuta egoteak zailtasunez betetzen du fitoteknologiaren diseinua, kutsatzaile-mota bakoitzak lurzoruan jokaera eta ezaugarri fisiko-kimiko desberdinak dituelako [18]. Puntu honetan, garrantzitsua da azpimarratzea edozein bio/fitorremediazio-prozesuren azkeneko helburua ez dela bakarrik lurzoruan dagoen kutsatzailearen kontzentrazioa murriztea araudiak finkatutako erreferentziazko balioetaraino, baizik eta ekosistema edafikoaren osasuna berreskuratzea [19].

Aipatutako erremediazio-bioteknologiak entzutetsu egiten ari dira ingurumenaren kudeaketa iraunkorraren alorrean, bereziki baliotsuak izanik bioekonomiaren esparruan. Azkeneko hamar urte hauetan, bioekonomiaren paradigma geroz eta erakargarriago bihurtu da arduradun politikoentzat. Ikuspuntu praktiko batetik, bioekonomia baliabide biologikoen ezagutzan oinarritzen da, zeinei zientzia eta teknologia aplikatzen zaizkien jakintza, ondasunak eta zerbitzuak lortzeko asmoz [22, 23]. Gure kasurako, esaterako, bio/fitorremediazio-teknologien bitartez osasuna/emankortasuna berreskuratzen duten lurzoru kutsatuak aktibo sozial eta ekonomiko baliotsu bilakatzen dira. Garapen iraunkorretik aldendu gabe eta gizarte-errentagarritasuna aintzakotzat hartuta, lurzoru horiek aisialdirako, elikagaien ekoizpenerako edo/eta berrurbanizaziorako eremu berde (greenfield) bihurtu daitezke, nahiz eta onartu behar den momentuz onura horien ustiaketa ziurgabetasunez beteta dagoela. 


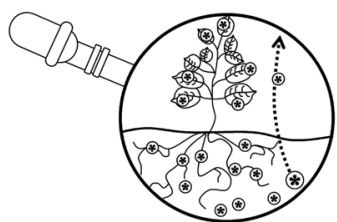

FITOERAUZKETA

Oinarria

Kutsatzaileak lurzorutik kentzea uztatu daitekeen landarearen biomasan metaketaren truke. Medeapenen (adib. EDTA edo bestelako agente mugitzaileak) erabiler konbinatuari "fitoerauzketa lagundua" deritzo Kutsatzailea(k) Metal(oide)ak Erabilitako landareak

Arabidopsis generoa (adib. A. halleri); artoa (Zea mays); berro alpinoa (Noccaea caerulescens); ekilorea (Helianthus annuus); frantses-belarra (Medicado sativa) Indiako ziapea (Brassica juncea); kalamua (Cannabis sativa); koltza (Brassica napus); makalak (Populus sp.); mingarratza (Rumex sp.); sahatsak (Salix sp.); tabakoa (Nicotina tabacum)

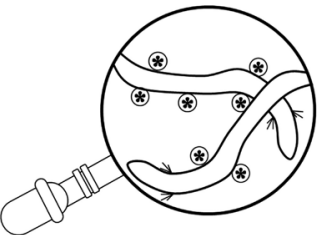

FITOEGONKORTZEA

(fitoibilgetzea \& fitobazterketa)

Oinarria

Kutsatzaileen bioeskuragarritasuna murriztea, sustrai-

sisteman edo/eta errizosferako biomasa bizian zein hildakoan.

Medeapenen erabilera konbinatuari "fitoegonkortze lagundua" deritzo

Kutsatzailea(k) Metal(oide)ak

Erabilitako landareak

Artoa; belar belarra (Poaceae Familia, adib., Festuca sp.) garagarra (Hordeum vulgare); Indiako ziapea; makalak; sahatsak; eskuhori zuria (Lupinus albus)

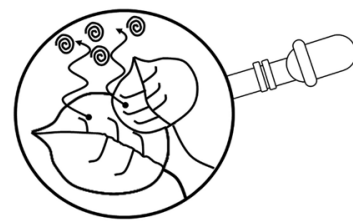

FITOLURRUNKETA

Oinarria

Kutsatzaileak lurzorutik xurgatu eta hostoaren azaleraren bitartez atmosferara lurrun moduan

askatzeari deritzo

Kutsatzailea(k)

Metal(oide)ak (lurrunkorretara mugatua) Organikoak

Erabilitako landareak Arabidopsis generoa (A. thaliana); Indiako ziapea; alga berdeak (adib. Chara canescens); Limako iratzea (Pteris vittata)

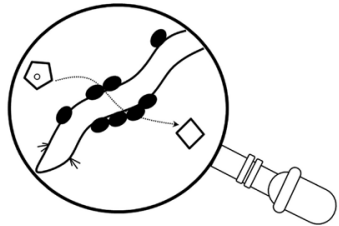

ERRIZODEGRADAZIOA

Oinarria

Landareen sustraien inguruko lurzoruan (errizosferan) dauden mikroorganismoen degradazio gaitasuna Kutsatzailea(k) Organikoak

Erabilitako landareak

Belarrak; betiberra (Chrysopogon zizanioides); Indiako belarra (Sorghastrum nutans L.); makalak; sahatsak

3. irudia. Fitorremediazio-tekniken oinarriak eta erabilitako landare-espezieak. Irudiaren iturria: [14]. Informazio gehiagorako, ikusi [5], [20] eta [21] artikuluak eta barneko erreferentziak.

\section{LURZORUEN FITORREMEDIAZIOA ETA FITOKUDEAKETAREN ADIBIDEAK: GREENLAND ETA PhytoSUDOE PROIEKTUAK}

Gaurko joerak aintzat hartuta, etorkizuna ez da oso itxaropentsua: badirudi 2025. urterako lurzoru kutsatuen kopurua bikoiztu egingo dela [24]. 
Izan ere, arazoaren dimentsioak identifikatu gabe dirau. Bitartean, erremediazio-programak (prozedura biologikoetan zein fisiko-kimikoetan - adib. hondeaketan eta zabortegietan biltegiratzean - oinarritutakoak) astiro doaz aurrera. Azken hamarkadetan, 51.000 gune besterik ez da kudeatu (potentzialki kutsatutakoen \% 15) [4]. Hori dela eta, egungo erremediazio-jardueren maila aintzat hartuta, lurzoru kutsatuen arazoa, gutxitu beharrean, haziz doa.

Erremediaziorako aukera bigunek onurak izan arren (ikusi 4. azpiatala), haien in situ aplikazioa oso mugatua da oraindik ere, bereziki Europan eta metal(oide)ekin kutsatutako lurzoruetan [25;26]. GRO tekniken aplikazio orokorrerako oztopo nagusiak erremediazio-sektorearen hurbilketa orokorretik eratortzen dira; bereziki, erremediazioaren arrisku kritikoetatik edo industriaguneei erabilera produktiboa azkarregi itzuli behar izatetik [16]. Azterketa pilotu sendoen gabezia eta araudi-esparru sendo baten falta ere oztopo nabarmenak dira [16;25]. Beharbada, agintari politikoek eta interesatuek GRO tekniken inguruan duten ezjakintasuna eta konfiantza-falta lirateke halakoen aplikazio baxuaren arrazoia. Batik bat GROen erabilgarritasun mugatua honako eragozpen hautemangarri (edo erreal) hauei zor zaie: (a) GROek behar duten denbora-eskalaren eta arriskuen kudeaketarako duten epe luzerako eraginkortasunaren inguruko ziurgabetasuna; (b) tekniken aplikazioaren eskaintza aholkulari eta kontratista gutxi batzuetara mugatuta egotea, gutxienez Europan; eta, azkenik, (c) teknika hauek in situ aplikatzeko irtenbide praktiko gisa kontuan ez hartzea [5;16].

Oztopo horiek gainditu nahian, EBk finantzatutako GREENLAND (Gentle Remediation of Trace Element Contaminated Land) proiektuak (2010-2015) [27] lurzoru kutsatuen kudeaketarako GRO teknikak erabiltzearen aldeko apustua egin zuen. Are gehiago, landa-ikerketak eta ebaluazioak egiteko eta erabakiak hartzeko tresna eta praktika onen gida garatzeko erronkei heldu zien. Praktika onen gida horrek fitorremediaziotik fitokudeaketarako aplikazio-ikuspuntua goratu nahi izan du. Fitokudeaketan kutsatzaileak erauzteko edo egonkortzeko gaitasuna duten eta aldi berean elikadurarako ez diren baina bestelako balioa (adib. energetikoa) izan dezaketen laboreak erabiltzen dira. Horrela, fitokudeaketan lurzoruak berreskuratzeak ekarriko lituzkeen onurak (ekonomikoak barne) fitorremediazio-estrategiaren diseinuaren erdigunean kokatzen dira. Hala, GROak abandonatutako eta kutsatutako lurzoruen arriskuen kudeaketan eta berreskurapenerako konponbide integralen artean kokatu edo/eta, bederen, eremu horien «mantentze-estrategia» gisa erabil daitezke [5]. Mantentze-estrategia horrek zera dakar: kutsatzaileen mugikortasuna, lixibiazioa, garraioa, bioeskuragarritasuna eta lurrunketa gutxitzea; lurzoru abandonatuen eta kutsatuen arriskua murriztea; biomasa ekoiztea; zerbitzuak eta aisialdirako guneak sortzea; ingurumena hobetzea; hiriko klima kudeatzea, edo ekosistemen zerbitzuak ematea, besteak beste [5]. 
Aurretik azaldu diren kontzeptuak oinarri harturik, PhytoSUDOE proiektuak (Interreg Sudoe deialdia, 2015-2018) [28] kudeatzaile eta lurzoru kutsatuen jabeen aldetik fitokudeaketa-tekniken erabilera zabalagoa bultzatzen du. Proiektuaren helburu nagusia, eta EBko lurzoruen erremediazio eta babesarekin lotutako helburuekin batean, ingurune degradatuak (fito)kudeatzea eta erremediatzea da, biodibertsitatea sustatzen duten fitorremediazio-teknika berriak aplikatuz, ekosistemen funtzionaltasun integrala (osasuna) hobetzeko eta baliabideen erabilera (kalitatea) iraunkorra ahalbidetzeko. PhytoSUDOE proiektuan fitokudeaketarako labore zein zuhaitzetan oinarritutako fitorremediazio-teknikak, lurzoru-zuzenketak eta bakterio endofito eta errizosferikoen inokulazioak erabiltzen dira.

Orain arte deskribatu ditugun fitorremediazio-tekniken aplikazioaren ahuleziak gainditzeko ezaugarriak ditu PhytoSUDOE proiektuak. Hasteko, Portugalgo, Espainiako eta Frantziako 10 bazkidek eta alor desberdinetako espezialistek (lurzoruaren geologiatik eta biologiatik agronomiara, paisaiaren plangintzara eta arriskuen ebaluaziora) osatutako lantaldea izateak fitokudeaketaren diseinuari eta emaitzen interpretazioari sendotasuna eta ikuspegi holistikoa ematen dizkie. Bigarrenik, aipatutako herrialdeetako 11 kokaleku kutsatu edo degradatuz osatutako esperimentu-sare baten ezarpenak eta jarraipenak aukera emango du fitokudeaketak lurzoruen erremediazio ekologikorako duen potentzialaren froga sendoak lortzeko. Kokaleku horietako bi EAEn daude; konkretuki Jundizko Industrialdean (Gasteizko mendebaldean). Proiektuaren azken indargunea, baina ez horregatik garrantzi gutxienekoa, interesatuen lurzoru degradatu/kutsatuekiko sentikortasuna eta fitokudeaketaren onuren inguruko ezagutza zabaltzea da, dibulgaziozko jardunaldiez baliatuz.

\section{ONDORIOAK}

Horrenbestez, eta laburpen gisa, lurzoru kutsatuen kudeaketaren inguruan hauek dira gure ustez garatu beharreko gaiak (lehenengoak premiazkoenak):

- Lurzoruen kutsadurari aurre hartzeko asmoz, horren inguruan interesatuek (batik bat politikariek, kudeatzaileak eta gizarteak) duten informazioa sakontzea eta sentikortasuna bultzatzea.

- Kutsadurari atxikitako arriskuen karakterizazioan (esposizioaren eta inpaktuaren ebaluazioan) eta bio/fitorremediazio-prozesuaren jarraipenean bioindikatzaileetatik eratorritako informazio integratzaileari garrantzi gehiago ematea.

- Lurzoru kutsatuen erremediazioari dagokionez, GROen onura ugariei balio erreala ematea eta haien erabilera bultzatzeko ekimenak 
garatzeko laguntza tekniko, sozial eta ekonomikoak sustatzea, udalerri, erkidego, estatu eta Europa mailan.

- Fitorremediazioa lurzoruak onbideratzeko ohiko teknologia bilaka dadin, epe luzeko landa-ikerketei lehentasuna ematea. Gainera, prozesua arrakastatsua izateko landareen eta lurzoruko mikroorganismoen arteko erlazioak ondo ezagutzea (bai maila molekularrean bai fisiologikoan) erabakigarria da. Horretarako, zalantzarik gabe, jakintza-alor askoren arteko hurbilketa bultzatzea beharrezkoa izango da.

- Lurzoru kutsatuen edo degradatuen (adib. metropoli-eraztunen ingurukoak) berreskurapen eta berrerabilera eraginkorrek epe laburrean dakartzaten berealdiko onura ekonomiko, sozial eta ekologikoak kuantifikatzea, jakinik hurrengo belaunaldietan ere berreskuratutako lurzoru horietatik eratorritako onurek iraungo dutela.

- Lurzoru kutsatuen babesa eta kudeaketa (espezifikoki) arautzen dituzten legeen eta gida teknikoen aplikazioa sustatzea.

\section{ESKER ONAK}

Eskerrik asko Eusko Jaurlaritzari (Ikerketa Talde Kontsolidatuak, GIC15/44-IT-018-16), Espainiako Ekonomia eta Lehiakortasun Ministerioari (NANORRIZOREM, AGL2015-64481-C2-1-R) eta FEDER Europako funtsen programari (PhytoSUDOE, SOE1/P5/E0189) emandako proiektuengatik. Bestalde, MT.G-S-k eskerrak eman nahi dizkio Euskal Herriko Unibertsitateari (UPV/EHU) doktoretza-ondoko diru-laguntzagatik.

\section{BIBLIOGRAFIA}

[1] WORLD WILDLIFE FUND WWF. 2016. Living Planet Report.

[2] FAO-Food and Agriculture Organization of United Nations. 2015a. «Healthy soils are the basis for healthy food production » informazio-orria.

[3] FAO-Food and Agriculture Organization of United Nations. 2015b. «Soil is a non-renewable resource. Its preservation is essential for food security and our sustainable future » informazio-orria.

[4] VAN LIEDEKERKE, M., PROKOP, G., RABL-BERGER, S., KIBBLEWHITE, M., eta LOUWAGIE, G. 2014. Progress in management of Contaminated Sites in Europe. EUR 26376, Publications Office of The European Union, Luxenburgo.

[5] CUNDY, A. B., BARDOS, R. P., PUSCHENREITER, M., MENCH, M., BERT, V., FRIESL-HANL, W., MÜLLER, I., LI, X.N., WEYENS, N., WITTERS, N., ETA VANGRONSVELD, J. 2016. «Brownfields to green 
fields: realising wider benefits from practical contaminant phytomanagement strategies». Journal of Environmental Management, 184, 67-77.

[6] RIZZO, E., PESCE, M., PIZZOL, L., ALEXANDRESCU, F. M., GIUBILATO, E., CRITTO, A., MARCOMINIA, A., eta BARTKE, S. 2015. «Brownfield regeneration in Europe: Identifying stakeholder perceptions, concerns, attitudes and information needs ». Land Use Policy, 48, 437-453.

[7] IHOBE-Eusko Jaurlaritzako Ingurumen eta Lurralde Politika Sailaren Ingurumen-Jarduketarako Sozietate Publikoa. 2017a. «Making a virtue of necessity - the case of a small region: the Basque Country». European achievements in soil remediation and brownfield redevelopment. A report of the European Information and Observation Network's National Reference Centres for Soil (Eionet NRC Soil). Payá Pérez A., A. eta Peláez Sánchez, S. (Edk). Europako Batasuna. doi:10.2760/818120

[8] http://www.euskadi.eus/eusko-jaurlaritza/ingurumen-lurralde-politika-saila/ hasiera/ Eguneratze-data: 2018/04/26.

[9] IHOBE-Eusko Jaurlaritzako Ingurumen eta Lurralde Politika Sailaren Ingurumen-Jarduketarako Sozietate Publikoa. 1998. Investigación de la contaminación del suelo: Valores indicativos de evaluación (VIE-A,VIE-B, VIE-C). Ingurumen, Lurralde Plangintza eta Etxebizitza Saila, Eusko Jaurlaritza. Vitoria-Gasteiz.

[10] VOLCHKO, Y., NORRMAN, J., ROSÉN, L., BERGKNUT, M., JOSEFSSON, S., SÖDERQVIST, T., NORBERG, T., WIBERG, K., eta TYSKLIND, M. 2014. «Using soil function evaluation in multi-criteria decision analysis for sustainability appraisal of remediation alternatives ». Science of the Total Environment, 485, 785-791.

[11] PANAGOS, P., VAN LIEDEKERKE, M., YIGINI, Y., eta MONTANARELLA, L. 2013. «Contaminated sites in Europe: review of the current situation based on data collected through a European network ». Journal of Environmental and Public Health, doi.org/10.1155/2013/158764.

[12] JENSEN, J., MESMAN, M. 2006. «Ecological risk assessment of contaminated land-Decision support for site specific investigations ». RIVM National Institute for Public Health and the Environment, Centre for Environmental Quality, txosten zenbakia 711701047. Bilthoven, Herbehereak.

[13] GÓMEZ-SAGASTI, M. T., EPELDE, L., ALKORTA, I., eta GARBISU, C. 2016. «Reflections on soil contamination research from a biologist's point of view ». Applied Soil Ecology, 105, 207-210.

[14] GÓMEZ-SAGASTI, M. T., ALKORTA, I., BECERRIL, J. M., EPELDE, L., ANZA, M., eta GARBISU, C. 2012. «Microbial monitoring of the recovery of soil quality during heavy metal phytoremediation». Water, Air, and Soil Pollution, 223, 3249-3262.

[15] EPELDE, L., BECERRIL, J. M., ALKORTA, I., eta GARBISU, C. 2014. «Adaptive Long-Term Monitoring of Soil Health in Metal Phytostabilization: Ecological Attributes and Ecosystem Services Based on Soil Microbial Parametersxs ». International Journal of Phytoremediation, 16, 971-981. 
[16] CUNDY, A. B., BARDOS, R. P., CHURCH, A., PUSCHENREITER, M., FRIESL-HANL, W., MÜLLER, I., NEU, S., MENCH, M., WITTERS, N. eta VANGRONSVELD, J. 2013. «Developing principles of sustainability and stakeholder engagement for «gentle» remediation approaches: The European context ». Journal of Environmental Management, 129, 283-291.

[17] ITRC-Interstate Technology Regulatory Council. 2009. «Phytotechnology Technical and Regulatory Guidance and Decision Trees, Revised ». Washington DC, Ameriketako Estatu Batuak (AEB).

[18] TRIPATHI, V., FRACETO, L. F., eta ABHILASH, P. C. 2015. «Sustainable clean-up technologies for soils contaminated with multiple pollutants: plantmicrobe-pollutant and climate nexus ». Ecological Engineering, 82, 330-335.

[19] HERNÁNDEZ-ALLICA, J., BECERRIL, J. M., ZARATE, O., eta GARBISU, C. 2006. «Assessment of the efficiency of a metal phytoextraction process with biological indicators of soil health ». Plant and Soil, 281, 147158.

[20] KHANNA, P.S. 2011. «Assessment of heavy metal contamination in different vegetables grown in and around urban areas ». Research Journal of Environmental Toxicology, 5, 162.

[21] KHALID, S., SHAHID, M., NIAZI, N. K., MURTAZA, B., BIBI, I., eta DUMAT, C. 2017. «A comparison of technologies for remediation of heavy metal contaminated soils ». Journal of Geochemical Exploration, 182, 247268.

[22] OECD-Organisation for Economic Co-operation and Development, 2009. The Bioeconomy to 2030: Desingning a Policy Agenda. Paris, Frantzia.

[23] LOISEAU, E., SAIKKU, L., ANTIKAINEN, R., DROSTE, N., HANSJÜRGENS, B., PITKÄNEN, K., LESKINEN, P., KUIKMAN, P., eta THOMSEN, M. 2016. «Green economy and related concepts: An overview ». Journal of Cleaner Production, 139, 361-371.

[24] GILLESPIE, I. M., eta PHILP, J. C. 2013. «Bioremediation, an environmental remediation technology for the bioeconomy ». Trends in Biotechnology, 31, 329-332.

[25] VANGRONSVELD, J., HERZIG, R., WEYENS, N., BOULET, J., ADRIAENSEN, K., RUTTENS, A., THEWYS, T., VASSILEV, A., MEERS, E., NEHNEVAJOVA, E., VAN DER LELIE, D., eta MENCH, M. 2009. «Phytoremediation of contaminated soils and groundwater: lessons from the field ». Environmental Science and Pollution Research, 16, 765794.

[26] MENCH, M., LEPP, N., BERT, V., SCHWITZGUEBEL, J.P., GAWRONSKI, S.W., SCHROEDER, P., eta VANGRONSVELD, J. 2010. «Successes and limitations of phytotechnologies at field scale: outcomes, assessment and outlook from COST Action $859 »$. The International Journal of Soil, Sediment and Water, 10, 1039-1070.

[27] www.greenland-project.eu. Eguneratze-data: 2015/01/25.

[28] http://www.phytosudoe.eu/en/. Eguneratze-data: 2018/01/25. 